\title{
Effects of Defined Mixtures of Persistent Organic Pollutants (POPs) on Multiple Cellular Responses in the Human Hepatocarcinoma Cell line, HepG2, using High Content Analysis Screening
}

\author{
Jodie Wilson ${ }^{a}$, Hanne Friis Berntsen ${ }^{b}$, Karin Elisabeth Zimmer $^{\mathrm{b}}$, Caroline Frizzell ${ }^{\mathrm{a}}$, Steven Verhaegen ${ }^{\mathrm{b}}$, \\ Erik Ropstad ${ }^{b}$, Lisa Connolly ${ }^{a}$ \\ a Institute for Global Food Security, School of Biological Sciences, Queen's University Belfast, \\ Northern Ireland, United Kingdom \\ ${ }^{\mathrm{b}}$ Norwegian University of Life Sciences, Oslo, Norway. \\ *Corresponding author: I.connolly@qub.ac.uk, +44 28 90976668; fax: +44 2890976513.
}

\section{Abstract:}

Persistent organic pollutants (POPs) are toxic substances, highly resistant to environmental degradation, which can bio-accumulate and have long-range atmospheric transport potential. Most studies focus on single compound effects, however as humans are exposed to several POPs simultaneously, investigating exposure effects of real life POP mixtures on human health is necessary. A defined mixture of POPs was used, where the compound concentration reflected its contribution to the levels seen in Scandinavian human serum (total mix). Several sub mixtures representing different classes of POP were also constructed. The perfluorinated (PFC) mixture contained six perfluorinated compounds, brominated $(\mathrm{Br})$ mixture contained seven brominated compounds, chlorinated (Cl) mixture contained polychlorinated biphenyls and also $p, p^{\prime}-$ dichlorodiphenyldichloroethylene, hexachlorobenzene, three chlordanes, three hexachlorocyclohexanes and dieldrin. Human hepatocarcinoma (HepG2) cells were used for $2 \mathrm{~h}$ and $48 \mathrm{~h}$ exposures to the seven mixtures and analysis on a CellInsight ${ }^{\mathrm{TM}}$ NXT High Content Screening platform. Multiple cytotoxic endpoints were investigated: cell number, nuclear intensity and area, mitochondrial mass and membrane potential (MMP) and reactive oxygen species (ROS). Both the $\mathrm{Br}$ and $\mathrm{Cl}$ mixtures induced ROS production but did not lead to apoptosis. The PFC mixture induced the 
ROS production and likely induced cell apoptosis accompanied by the dissipation of MMP. Synergistic effects were evident for ROS induction when cells were exposed to the PFC+Br mixture. No significant effects were detected in the $\mathrm{Br}+\mathrm{Cl}, \mathrm{PFC}+\mathrm{Cl}$ or total mixtures, which contain the same concentrations of chlorinated compounds as the $\mathrm{Cl}$ mixture plus additional compounds; highlighting the need for further exploration of POP mixtures in risk assessment.

Keywords:

Persistent organic pollutants; mixtures; cytotoxicity; high content analysis.

\section{Introduction}

Persistent organic pollutants (POPs) are toxic substances, highly resistant to environmental degradation, which can bio-accumulate and have long-range atmospheric transport potential (UNEP 2001) therefore potential effects on human health need to be investigated. POPs such as polychlorinated biphenyls (PCBs) and polybrominated diphenyl ethers (PBDEs) are well established pollutants (de Wit 2010; Letcher et al. 2010). Due to their lipophilic nature and resistance to degradation, POPs accumulate in living organisms and biomagnify in food chains (de Wit et al. 2004), resulting in high levels in tissues of top predators and humans (Bytingsvik et al. 2012; Muir and de Wit 2010). POPs are of global concern and have been detected in human adipose tissue, serum and breast milk samples collected in Asia, Europe, North America and the Arctic (Bi et al. 2006; Pereg et al. 2003; Sjödin et al. 1999; Sjödin et al. 2008).

Exposure to POPs has been associated with adverse effects in animals including neurobehavioural development disruption (Johansson et al. 2008), impaired memory and learning (Kuriyama et al. 2005; Viberg et al. 2003) and disruption of neural proteins involved in synapse formation and growth (Johansson et al. 2009). Other effects include liver hypertrophy, alteration in liver enzymes, hepatomegaly and tumours (Butenhoff et al. 2004), developmental problems in 
1 rodent offspring exposed in utero (Lindstrom et al. 2011) and evidence of endocrine disruption

2 (White et al. 2011).

3

Evidence of endocrine disrupting potential, as well as other harmful effects from POPs have been reported in humans. Importantly, studies have shown that POPs can cross the placenta and accumulate in the foetus (Beesoon et al. 2011; Inoue et al. 2004; Ode et al. 2013). Prenatal exposure to POPs has been associated with effects on birth weight, duration of pregnancy, visual memory (Van Oostdam et al. 2003), impaired immune function (Heilmann et al. 2006) and increased risk of middle ear infections (Dewailly et al. 2000). Furthermore babies are exposed to POPs through breast feeding (Llorca et al. 2010; Waliszewski et al. 2009). This implies that they are exposed before birth and during the early sensitive developmental stages of their lives to POPs. The endocrine disrupting potential of POPs in humans has also been highlighted (Bonde et al. 2008; Longnecker et al. 2007; Lyche et al. 2011). Exposure to POPs has been associated with decreased fertility (Harley et al. 2010) and infertility in women (Fei et al. 2009), altered sex hormone and thyroid hormone homeostasis (Ellis-Hutchings et al. 2006; Hallgren and Darnerud 2002; Persky et al. 2001), dermatological effects such as rashes and acne (Ritter et al. 1995) and type 2 diabetes (Grandjean et al. 2011).

Animals and humans are exposed to mixtures of POPs. Therefore investigating the effect of one POP in isolation is not representative of real life exposure. Instead it is more important to look at how mixtures of POPs work in combination to affect health. Only single compound exposure is currently considered by risk assessment authorities (Kortenkamp 2007), potentially leading to an ignorance of additive, synergistic or antagonistic effects and the misinterpretation of the risk of POP exposure as complex mixtures. The toxicological determination of complex mixtures has been highlighted as one of the most important challenges for modern toxicology (Fent 2003; Kortenkamp 2007; Vaiseman 2011). In the present study, the effect of complex mixtures on several cellular responses, in an in vitro liver model using human hepatocarcinoma (HepG2) cells, was studied. High Content Analysis (HCA) was used in conjunction with the conventional 3-(4,5-dimethylthiazol-2-yl)2,5 diphenyltetrazolium bromide (MTT) assay. HCA is a novel, high-throughput, quantitative 
fluorescence technique that can examine chemical induced toxicity at sub-cellular microscopic resolution. It amalgamates fluorescence microscopy with automated cell analysis software allowing the simultaneous assessment of multiple morphological and functional cell parameters (Abraham et al. 2004; Giuliano et al. 2003). Using toxicity assays, HCA can detect subtle pre-lethal changes in cell health rather than obvious lethal cytotoxicity detected by the conventional MTT assay ( $O^{\prime}$ Brien 2008; O'Brien and Haskins 2007). The liver is the main metabolic organ for degrading xenobiotics. As such the liver often shows the earliest signs of injury, and therefore it is useful to model the effects of POP mixtures on a liver cell line. Furthermore, POPs such as PCBs tend to accumulate in the liver (Bachour et al. 1998). It may be assumed that primary human hepatocytes would be most appropriate for use in predicting human toxicity however these cells dedifferentiate over the time of the assay. Furthermore as they are non-proliferative critical toxicity parameters would be lost. HepG2 are considered to be one of the best single-cell models for predicting human toxicity potential (O'Brien 2014). They are also highly sensitive in the recognition of effects on mitochondrial DNA and mitochondrial function (Pinti et al. 2003). This sensitivity coupled with the ability to incorporate multiple parameters suggests that HCA, using HepG2 cells, is an appropriate candidate for investigating POP mixtures.

Assay parameters which can be optimised and measured using HCA include: cell number $(\mathrm{CN})$, nuclear area (NA), nuclear intensity (NI), mitochondrial membrane potential (MMP), mitochondrial mass (MM) and reactive oxygen species (ROS). These markers cover cellular metabolic functions and are markers of cell health (O'Brien 2008; O'Brien and Haskins 2007; Walsh et al. 2011). O'Brien et al. (2006) reported that the most sensitive HCA toxicity parameters in HepG2 cells are cell proliferation, mitochondrial health and NA. Enhanced biogenesis of mitochondria can increase MM due to increased mitochondrial respiration and this often corresponds with reduced MMP ( $\mathrm{O}^{\prime}$ Brien and Haskins 2007). Mitochondria serve as a site of regulation of programmed cell death (apoptosis). Apoptosis can occur when cells are damaged by disease or noxious agents (Norbury and Hickson 2001). A hallmark of early apoptosis is cell shrinkage and pyknosis which is the condensation of 
chromatin in the nucleus (Kerr et al. 1972). Necrosis is an alternative to apoptotic cell death by which the cell passively follows an energy-independent mode of death. The cells will swell in contrast to apoptotic cells which shrink. Although there are distinct differences in the mechanisms of apoptosis and necrosis, there is overlap between the two processes described as the "apoptosisnecrosis continuum" (Zeiss 2003). O'Brien et al. (2006) highlighted the need to incorporate an oxidative stress biomarker in HCA screening. Excessive ROS can induce oxidative damage in cells and impair cellular functions (Aims et al. 1993; Halliwell and Gutteridge 1999). Cellular antioxidants protect against the damaging effects of ROS. However, in moderate concentrations, ROS are necessary for a number of protective reactions (Halliwell and Gutteridge 1999). multi-parameter HCA cytotoxicity assay for the study of exposure of HepG2 cells to POP mixtures. It is important to assess POPs in mixtures as it reflects real life exposure and it may be possible to highlight the mechanisms by which POP mixtures induce toxicity, particularly pre-lethal toxicity. Furthermore comparison of the conventional MTT cytotoxicity assay coupled with the HCA assay will help determine if HCA can be used to better measure POP mixture toxicity. While individual POPs have been the focus of many studies, mixtures of POPs have not been extensively examined. Investigations of POP mixtures are crucial as the evidence of their health effects on humans and animals is irrefutable.

\section{Materials and Methods}

\subsection{Chemicals}

All PBDEs, PCBs and other organochlorines were originally purchased from Chiron As (Trondheim, Norway). All perfluorinated compounds (PFCs) were obtained from Sigma-Aldrich (St. Louis, MO, USA) except PFHxS which was from Santa Cruz (Dallas, US). Hexabromocyclododecane (HBCD), 
(MTT) and menadione were obtained from Sigma-Aldrich (Dorset, UK). CellROX Deep Red reagent and other cell culture reagents were supplied by Life Technologies (Paisley, UK) unless otherwise stated. Mitochondrial membrane potential dye (MMPD) and Hoechst nuclear stain 33342 were purchased from Perbio (Northumberland, England). All other reagents were standard laboratory grade.

\subsection{Mixtures}

Mixtures of the test POPs were designed and premade by the Norwegian University of Life Sciences, Oslo. Seven mixtures were used in the cell assays (Table 1): (1) total mixture, containing all the test compounds, (2) perfluorinated mixture (PFC), (3) brominated mixture (Br), (4) chlorinated mixture (Cl), (5) perfluorinated and brominated mixture (PFC $+\mathrm{Br}$ ), (6) perfluorinated and chlorinated mixture $(\mathrm{PFC}+\mathrm{Cl})$ and $(7)$ brominated and chlorinated mixture $(\mathrm{Br}+\mathrm{Cl})$. The chemicals included in the mixtures and their respective concentrations in the stock solution are shown in Table 1 (Berntsen et al. 2015). The POP mixtures used in this study were based on concentrations of relevant POPs measured in human blood, according to recent studies of the Scandinavian population (Haug et al. 2010; Knutsen et al. 2008; Polder et al. 2008; Polder et al. 2009; Van Oostdam et al. 2004) as described in Berntsen et al. (2015). The compounds were mixed in concentration ratios relevant to human exposure. The stocks of the total mixture, $\mathrm{Cl}$ mixture and the $\mathrm{Cl}$ sub-mixtures were ten times more diluted compared to the PFC and the $\mathrm{Br}$ mixtures and the combined $\mathrm{PFC}+\mathrm{Br}$ sub-mixture.

\subsection{Cell Culture and Treatment}

HepG2 cells were routinely cultured in a humidified atmosphere of $5 \% \mathrm{CO}_{2}$ at $37{ }^{\circ} \mathrm{C}$. Cells were grown in $75 \mathrm{~cm}^{2}$ flasks in MEM media supplemented with $10 \%$ foetal bovine serum, $2 \mathrm{mM}$ LGlutamine, $1 \%$ penicillin-streptomycin and $1 \mathrm{mM}$ sodium pyruvate. TrypLE ${ }^{\mathrm{TM}}$ Express trypsin was used to disperse the cells from the flasks, while cell counting and viability checks prior to seeding plates were achieved by trypan blue staining and using a Countess ${ }^{\circledast}$ automated cell counter. 

(BD Biosciences, Bedford, MA, US) at a density of $6 \times 10^{4}$ cells $/ \mathrm{ml}$ and allowed to attach for $24 \mathrm{~h}$. The cells were then exposed to $1 / 1000,1 / 2000,1 / 10000$ and $1 / 20000$ dilutions of the original stocks, which corresponded to $10000,5000,1000$ and 500 times the levels in serum for $\mathrm{PFC}, \mathrm{Br}$ and $\mathrm{PFC}+\mathrm{Br}$ mixtures. For the remaining mixtures (total, $\mathrm{Cl}, \mathrm{PFC}+\mathrm{Cl}$ and $\mathrm{Br}+\mathrm{Cl}$ ) the exposures corresponded to $1000,500,100$ and 50 times the levels in serum. The dilutions were performed in the same media as stated above. Incubation periods were: $2 \mathrm{~h}$ or $48 \mathrm{~h}$. A solvent control of $0.2 \%$ (v:v) DMSO in media was also included. The duration of exposure for the study was chosen to cover early cellular events/effects and the eventual consequences thereof after $48 \mathrm{hr}$ exposure.

\subsection{Analysis of Multiple Cellular Parameters by High Content Analysis (HCA)}

Cellomics ${ }^{\circledR}$ High Content Screening reagent series multi-parameter cytotoxicity dyes were used by following manufacturer's instructions. MMPD was prepared by adding $117 \mu \mathrm{l}$ of DMSO to make a 1 $\mathrm{mM}$ stock solution. The live cell stain was prepared by adding $6.75 \mu \mathrm{l}$ of the MMPD and $27 \mu \mathrm{l}$ of CellROX reagent (resulting in a final cell exposure concentration of $5 \mu \mathrm{M}$ ) in $1500 \mu \mathrm{l}$ of media for each assay plate. Following incubation, the plate was protected from light and $25 \mu \mathrm{l}$ of live cell stain was added to each well for $30 \mathrm{~min}$ at $37^{\circ} \mathrm{C}$. Cells were fixed with $10 \%$ formalin solution for $20 \mathrm{~min}$ at room temperature (RT) and washed with PBS. Hoechst 33342 dye (at a final concentration of 1.6 $\mu \mathrm{M}$ ) was added to each well and incubated for $10 \mathrm{~min}$ at RT, after which cells were washed with PBS. The wells were then filled with $200 \mu \mathrm{PBS}$, sealed with a plate sealer and evaluated on Celllnsight ${ }^{\mathrm{TM}}$ NXT High Content Screening (HCS) platform (Thermo Fisher Scientific, UK). This instrument analyses NA. MMPD was used to evaluate parameters of mitochondrial function: MMP and MM. CellROX ${ }^{\circledR}$ 
magnification in the selected excitation and emission wavelengths for Hoechst dye (Ex/Em 350/461 nm), MMPD (Ex/Em 554/576 nm) and CellROX reagent (Ex/Em 640/665 nm). Nine field view images were acquired in each well to examine each parameter.

\subsection{MTT Assay}

As well as visual inspection of the HepG2 cells under the microscope to evaluate cell morphology and attachment, the MTT cell viability assay was performed to act as a comparison to the HCA cytotoxicity assay.

The cells were exposed exactly as in Section 2.3 after which the percentage of viable cells was determined. In the MTT assay viable cells convert the soluble yellow MTT to insoluble purple formazan by the action of mitochondrial succinate dehydrogenase. The cells were washed once with PBS. MTT solution (50 $\mu \mathrm{l}$ of $2 \mathrm{mg} / \mathrm{ml}$ stock in PBS diluted 1:2.5 in assay media) was added to each well and the cells incubated for $3 \mathrm{~h}$. The supernatant was removed and $200 \mu \mathrm{l}$ of DMSO was added to dissolve the formazan crystals. Subsequently, the plate was incubated at $37^{\circ} \mathrm{C}$ with agitation for $10 \mathrm{~min}$. Absorbance was measured at $570 \mathrm{~nm}$ with a reference filter at $630 \mathrm{~nm}$ using a microtitre plate reader (TECAN, Switzerland). Viability was calculated as the percentage absorbance of the sample compared to the absorbance of the solvent control.

\subsection{Statistical Analysis}

Exposures were carried out in triplicate wells and three independent exposures performed. The coefficient of variation (CV) was calculated for the three exposures; all parameters were below $15 \%$ except for ROS production which was below 25\%. Data was analysed using Microsoft Excel and Graphpad PRISM software, version 5.01 (San Diego, CA). All values shown are expressed as mean \pm standard error of the mean (SEM) of the independent exposures. Data is expressed as a percentage of untreated (solvent) control for each parameter. Data was analysed by one-way ANOVA followed by Dunnett's procedure for multiple comparisons; the mean concentrations were tested for 
significant difference at the $95 \%$ confidence level. A $p$ value of $\leq 0.05$ was considered as significant, $p$ $\leq 0.05(*) \leq 0.01(* *) \leq 0.001(* * *)$.

\subsection{Comparison between expected and measured results}

The expected values were calculated by addition of the mean value after exposure to one mixture (e.g. PFC mixture) alone with the mean value obtained after exposure to the second mixture (e.g. $\mathrm{Br}$ mixture) (Weber et al. 2005). For example:

$$
\text { Mean (expected for PFC }+\mathrm{Br})=\text { mean }(\mathrm{PFC})+\text { mean }(\mathrm{Br})-100 \%
$$

Furthermore to calculate expected SEM, the following equation was used:

$$
\text { SEM (expected for PFC }+\mathrm{Br})=\left[(\mathrm{SEM} \text { for PFC })^{2}+(\mathrm{SEM} \text { for } \mathrm{Br})^{2}\right]^{1 / 2}
$$

An unpaired t-test was used to calculate the significance of difference in the expected and measured values, with $p \leq 0.05$ being considered statistically significant. Interpretation of the results were as follows:

- Additive effects: measured values were not significantly higher or lower than expected values.

- Synergistic effects: measured values were significantly below expected values for parameters $\mathrm{CN}, \mathrm{NI}$ and MMP and significantly above for parameters NA, MM and ROS.

- Antagonistic effects: measured values were significantly above expected values for parameters $\mathrm{CN}, \mathrm{NI}$ and MMP and significantly below for parameters NA, MM and ROS.

\section{Results}

HCA methodology multiple parameters (CN, NA, NI, MM, MMP and ROS) representative for different cellular events and functionality were measuring using HepG2 cells exposed to defined POP mixtures. In parallel, cytotoxicity was measured using a standard MTT assay procedure. 
Exposure ( $2 \mathrm{~h}$ ) to the highest concentrations of the PFC mixture (equivalent to 5000 and 10000 times serum levels) reduced cell viability to $82.4 \%$ and $55.5 \%$ respectively ( $p \leq 0.05, p \leq 0.001$, Figure 1 ). exposure with the highest concentration of PFC $+\mathrm{Br}$ mixture, $66.9 \%$ cell viability $(p \leq 0.001$, Figure 1). Reductions in cell viability were evident after $48 \mathrm{~h}$ exposure for the two highest concentrations of this mixture, $1.2 \%$ and $0.9 \%$ respectively ( $p \leq 0.001$, Figure 1 ). Total, $\mathrm{Br}, \mathrm{Cl}, \mathrm{PFC}+\mathrm{Cl}$ and $\mathrm{Br}+\mathrm{Cl}$ mixtures had no significant cytotoxic effects in the MTT assay (data is not shown for these mixtures as no significant effects were found; $\mathrm{Br}$ is included only to enable comparisons to PFC with and without $\mathrm{Br}$ ).

\subsection{Cytotoxicity as measured by $C N, N A$ and NI}

196

Exposure ( $2 \mathrm{~h}$ ) to the highest concentration of the PFC mixture reduced $\mathrm{CN}$ to $40.9 \%$ ( $p \leq 0.01$; Figure

2A). $\mathrm{CN}$ was also found to be significantly decreased after $48 \mathrm{~h}$ exposure to this mixture at the two highest concentrations, $1.7 \%$ and $0.8 \%$ cell viability respectively ( $p \leq 0.001$; Figure $2 \mathrm{~A})$. Similarly, $48 \mathrm{~h}$ and $1.3 \%$ cell viability respectively ( $p \leq 0.001$; Figure $2 \mathrm{~A})$.

202

$\mathrm{NI}$ was found to be significantly increased after $48 \mathrm{~h}$ exposure to the PFC mixture at the two highest concentrations, $166.3 \%$ and $156.9 \%$ nuclear intensity respectively ( $p \leq 0.01, p \leq 0.05$; Figure $2 \mathrm{~B}$ ). The $\mathrm{PFC}+\mathrm{Br}$ mixture at the two highest concentrations was also found to increase nuclear intensity, $153.7 \%$ and $142.0 \%$ respectively ( $p \leq 0.001, p \leq 0.01$; Figure 2B). Even during the $2 \mathrm{~h}$ exposure the 
highest concentration of the PFC $+\mathrm{Br}$ mixture was found to significantly increase nuclear intensity to $127.3 \%(p \leq 0.01$; Figure $2 \mathrm{~B})$.

NA was found to be significantly increased after $48 \mathrm{~h}$ exposure to the PFC mixture (equivalent to 5000 times serum levels), $187.2 \%$ nuclear area ( $p \leq 0.001$, Figure $2 \mathrm{C}$ ). Exposure $(2 \mathrm{~h})$ to the $\mathrm{PFC}+\mathrm{Br}$ mixture at the highest concentration decreased nuclear area to $68.5 \%$ ( $p \leq 0.05$, Figure $2 \mathrm{C}$ ). However, after $48 \mathrm{~h}$ exposure, the two highest concentrations were found to increase nuclear area, $164.9 \%$ and $196.6 \%$ respectively ( $p \leq 0.001$, Figure $2 C$ ).

The other mixtures (total, $\mathrm{Br}, \mathrm{Cl}, \mathrm{PFC}+\mathrm{Cl}$ and $\mathrm{Br}+\mathrm{Cl}$ ) caused no significant changes to $\mathrm{CN}, \mathrm{NA}$ or $\mathrm{NA}$ (data is not shown for these mixtures as no significant effects were found; $\mathrm{Br}$ is included only to enable comparisons to PFC with and without $\mathrm{Br}$ ).

\subsection{Cytotoxicity as measured by MM and MMP}

All concentrations of the $\mathrm{Cl}$ mixture $(100,500$ and 1000 times serum levels), apart from the most dilute (50 times serum levels), were found to significantly increase MM to $106.6 \%, 108.5 \%$ and $109.7 \%$ respectively ( $p \leq 0.05, p \leq 0.01$ and $p \leq 0.001$, Figure 3 ) after $48 \mathrm{~h}$ exposure. Although the results are statistically significant, the biological significance is likely to be minor as these inductions are very low.

The only mixture to show significant changes in $\mathrm{MM}$ after $2 \mathrm{~h}$ exposure was the $\mathrm{Br}$ mixture (at 1000 times serum levels), increasing to $109.4 \%$ ( $p \leq 0.01$, Figure 4A). However MM increased significantly after $48 \mathrm{~h}$ exposure to the PFC mixture at the two highest concentrations, to $160.9 \%$ and $172.5 \%$ mitochondrial mass ( $p \leq 0.01$, Figure $4 \mathrm{~A})$. The PFC $+\mathrm{Br}$ mixture at the highest concentration was also found to increase MM to $206.5 \%$ ( $p \leq 0.05$, Figure $4 A$ ). 
MMP decreased significantly after $2 \mathrm{~h}$ and $48 \mathrm{~h}$ exposure to the PFC mixture at the two highest concentrations to $64.1 \%$ and $46.6 \%(p \leq 0.001)$ and $22.3 \%$ and $11.7 \%$ respectively $(p \leq 0.001$, Figure 4B). Exposure ( $2 \mathrm{~h}$ ) to the PFC $+\mathrm{Br}$ mixture at the highest concentration was found to decrease MMP to $66.7 \%$ ( $p \leq 0.05$, Figure 4B). After $48 \mathrm{~h}$ exposure the two highest concentrations were also found to decrease MMP to $40.0 \%$ and $25.5 \%$ respectively ( $p \leq 0.001$, Figure $4 \mathrm{~B}$ ).

The total, $\mathrm{PFC}+\mathrm{Cl}$ and $\mathrm{Br}+\mathrm{Cl}$ mixtures caused no significant changes to $\mathrm{MM}$ or MMP (MM shown in Figure 3, MMP data not shown).

\subsection{Oxidative Stress}

Increased ROS production was detected after $2 \mathrm{~h}$ exposure to the highest concentration of the PFC mixture, $\mathrm{Br}$ mixture, $\mathrm{Cl}$ mixture and $\mathrm{PFC}+\mathrm{Br}$ mixture $(190.1 \% p \leq 0.001,149.5 \% p \leq 0.05,137.3 \% p \leq$ 0.05 and $348.4 \% p \leq 0.001$, Figure 5). The increase in red fluorescence after $2 \mathrm{~h}$ exposure to the highest concentration of PFC $+\mathrm{Br}$ mixture can be seen in Figure 6 . The second highest concentration (500 times serum levels) of the $\mathrm{Cl}$ mixture also caused significant increase in ROS $135.2 \%(p \leq 0.05$, Figure 5).

Increased ROS production was detected after $48 \mathrm{~h}$ exposure to the highest concentration of PFC mixture, $\mathrm{Br}$ mixture, $\mathrm{Cl}$ mixture and $\mathrm{PFC}+\mathrm{Br}$ mixture $(466.7 \% p \leq 0.001,178.1 \% p \leq 0.01,141.1 \% p \leq$ 0.01 and $525.3 \% p \leq 0.001$ respectively, Figure 5 ).

The total, $\mathrm{PFC}+\mathrm{Cl}$ and $\mathrm{Br}+\mathrm{Cl}$ mixtures caused no significant changes in ROS production (data not shown).

A summary of the results are shown in table 2 ( $2 \mathrm{~h}$ exposure) and table 3 ( $48 \mathrm{~h}$ exposure). 


\subsection{Assessing the interactive effects of the PFC $+B r$ mixture}

The addition of the $\mathrm{Br}$ mixture to the PFC mixture produced some interesting results. After $2 \mathrm{~h}$ incubation, no significant change in $\mathrm{CN}$ was observed for the highest concentration of $\mathrm{PFC}+\mathrm{Br}$ mixture; keeping in mind that the PFC mixture alone at this concentration lowered $\mathrm{CN}$ to $40.9 \%$. However this observed value was not deemed statistically significant from the expected value $p>$ 0.05 . In contrast a synergistic effect was evident for this concentration for MM with a $28 \%(p \leq 0.05)$ difference between expected and observed values. Furthermore for ROS production ( $2 \mathrm{~h}$ ) exposure to the PFC $+\mathrm{Br}$ mixture (at 5000 times serum levels) was deemed to reflect synergistic effects between the individual mixtures as the observed ROS value (188\%) was significantly higher than the expected value $(113 \%, p \leq 0.05)$. However the ROS production induced by the highest concentration (348\%, 10000 times serum levels) was not deemed to be statistically significantly different to the expected value (239\%) and is therefore considered additive. Exposure for $48 \mathrm{~h}$ to the PFC $+\mathrm{Br}$ mixture again resulted in higher ROS production than expected after exposure to each of the mixtures independently. The values observed for 1000 and 5000 times serum levels were deemed to be synergistic $(p \leq 0.05)$ while 500 and 10000 times serum levels were additive.

\section{Discussion}

Compared to single end-point cytotoxicity assays, HCA has the scope to investigate different mechanistic endpoints for cellular health and death simultaneously and therefore might better demonstrate the risk of human exposure to complex mixtures of environmental contaminants.

Cell population count or $\mathrm{CN}$, followed by $\mathrm{NA}$, are the most affected by cytotoxic drugs ( $O^{\prime}$ Brien 2014). There was a high result concordance between using the MTT assay (Figure 1) and CN as a measure of cell viability (Figure $2 \mathrm{~A}$ ). For $48 \mathrm{~h}$ exposure, the same mixtures and concentrations (PFC and PFC $+\mathrm{Br}$ ) were highlighted as statistically significant by both assays. However for $2 \mathrm{~h}$ exposure, the HCA parameter CN highlighted fewer mixtures and concentrations as toxic than the MTT assay. Since the MTT assay determines mitochondrial activity it is crucial to include the HCA 
mitochondrial parameters as a comparison. When these are considered the HCA showed MM changes in two mixtures, $\mathrm{Cl}$ (Figure 3) and $\mathrm{Br}$ mixtures (Figure 4A), that the MTT assay failed to highlight. Therefore combined HCA endpoints were found to be more sensitive at detecting cytotoxicity and revealed toxic effects where the conventional MTT endpoint showed none. study are unique to this collaborative group. Cellular effects of single PFCs on HepG2 cells have previously been reported for PFOA, ranging from cell cycle perturbations (starting at $50 \mu \mathrm{M}$ ), apoptosis $(200-450 \mu \mathrm{M})$, to necrosis $(400-500 \mu \mathrm{M})$ (Shabalina et al. 1999). Florentin et al. (2011) observed a reduction in viability after exposure to PFOA $(200 \mu \mathrm{M})$ or PFOS $(300 \mu \mathrm{M})$ for $24 \mathrm{~h}$. Hu and Hu (2009) reported a similar concentration-dependent decrease in cell viability for PFOA and PFOS, and pointed to additive effects in combined exposures. These concentration ranges correspond to the two highest concentrations of the PFC mixtures used in the present study, containing 54/109 $\mu \mathrm{M}$ and $273 / 546 \mu \mathrm{M}$ of PFOA and PFOS respectively, where a significant reduction in cell viability (measured by MTT and CN) was observed after 48 h. However, whereas Florentin et al. (2011) reported no cytotoxicity after $1 \mathrm{~h}$, a significant decrease in viability (measured by $\mathrm{CN}$ ) was evident after $2 \mathrm{~h}$ for the two highest concentrations of the PFC mixture in our study. This may indicate that the $\mathrm{CN}$ parameter in the HCA is more sensitive in detecting early onset of cytotoxic alterations. apoptosis and necrosis, depending on concentration and exposure time, suggesting on overlap between the two processes described as the "apoptosis-necrosis continuum" (Zeiss 2003). Indeed, in the present study changes in specific HCA endpoints were indicative of both modes of cell death. One apoptosis-induction pathway is mediated by early mitochondrial alterations, with the opening of the mitochondrial permeability transition (MPT) pore resulting in the release of mitochondrial proteins which initiate and execute the process of cell destruction. This mitochondrial dysfunction is reflected by a decrease in MMP, generally considered an early marker for this pathway (Bernardi et al. 1992; Gottlieb et al. 2003). A decrease in MMP may be expected to accompany an increase in 
MM as disruption of MMP/MPT pore opening induces mitochondrial swelling (Minamikawa et al. 1999). A reduction in MMP was evident after $2 \mathrm{~h}$ incubation with the PFC mixture $(64.1 \%$ at 5000 , and $46.6 \%$ at 10000 times serum levels; Figure $4 \mathrm{~B}$ ), after $48 \mathrm{~h}$ exposure the MMP decreased further while the MM had increased. Nuclear shrinkage is a hallmark of apoptosis while the swelling of nuclei is linked to compound-induced necrosis. In contrast to the changes indicative of apoptosis observed for the PFC mixture (5000 times serum levels) at 2 and $48 \mathrm{~h}$, the findings at $48 \mathrm{~h}$ of significantly increased NA would be indicative of nuclear swelling and necrosis (Figure 2C). NA was not significantly changed for the higher concentration of the PFC mixture, however $\mathrm{CN}$ was found to be reduced significantly, suggesting that any apoptotic or necrotic cells had been lost at this point.

ROS are a known mediator of apoptosis, and the opening of the MPT pore can be initiated and augmented by elevated ROS (Atlante et al. 2000). In the HCA assay ROS production was measured using the cell-permeable CellROX ${ }^{\circledR}$ Deep Red Reagent, which locates to the cytoplasm, and exhibits a strong fluorescent signal upon oxidation. The induction of ROS was observed after $2 \mathrm{~h}$ and $48 \mathrm{~h}$ exposure to the highest concentration of the PFC mixture (Figure 5). Similar studies with PFOA and PFOS (Hu and Hu 2009; Panaretakis et al. 2001) also reported induction of ROS. It is reasonable to deduce that the PFC mixture containing PFOA and PFOS potentially exerts its toxic effects on HepG2 cells through ROS-mediated cell apoptosis. It is possible that the loss of MMP and the increase in ROS are not two separate ways of inducing apoptosis but rather that they are linked. Damaged mitochondria are a major source of ROS. Excessive ROS may cause the mitochondria further damage, reducing MMP and consequently inducing apoptosis (Ricci et al. 2003; Simizu et al. 1998). This further supports the observation that the PFC mixture can induce apoptosis in HepG2 cells. However, further investigation is required to fully elucidate the mechanism.

No decrease in cell viability, measured using MTT or CN, was seen at any concentration or exposure time after exposure to the $\mathrm{Cl}$ mixture. However, $\mathrm{MM}$ was significantly increased after $48 \mathrm{~h}$ exposure to the $\mathrm{Cl}$ mixture at all concentrations tested above 50 times serum levels (Figure 3). Exposure to the $\mathrm{Cl}$ mixture also increased ROS production, after both $2 \mathrm{~h}$ exposure (500 and 1000 
times serum levels), as well as after $48 \mathrm{~h}$ exposure (1000 times serum levels; Figure 5). Exposure to individual PCBs has been shown to lead to uncontrolled ROS accumulation and cellular oxidative stress (Liu et al. 2012). Mitochondria can also swell in a fully reversible manner, without inducing cell death (Minamikawa et al. 1999; Petronilli et al. 1994). Therefore the level of ROS produced by the HepG2 cells after exposure to the $\mathrm{Cl}$ mixture may have been sufficient to open the MPT pore and cause mitochondrial swelling but not enough to irreversibly damage the cells. This further illustrates the ability of the HCA assay to pick up early signs and/or reversible signs of cellular stress.

Incubation of HepG2 cells with the $\mathrm{Br}$ mixture for $2 \mathrm{~h}$ and $48 \mathrm{~h}$ did not produce any significant changes in the MTT assay or CN, NI, NA, MMP parameters in the HCA. Studies have investigated the effects of single PBDEs on different cell types. BDE-47 and BDE-99 (0.1-10 $\mu \mathrm{M})$ proved non- cytotoxic for proliferating or differentiating human neural progenitor cells over a period of 2 weeks (Schreiber et al. 2010). However, cytotoxicity due to the induction of apoptosis has been reported for single PBDEs in rat cerebellar granule cells (Reistad et al. 2006), human astrocytoma cells (Madia et al. 2004), hippocampal neurons, human neuroblastoma cells, human foetal liver hematopoietic cells (He et al. 2008, He et al. 2009; Shao et al. 2008) and HepG2 cells (Hu et al. 2007). These studies tested much higher levels of the individual PBDEs than those present in the $\mathrm{Br}$ mixture. For example, Hu et al. (2007) tested 1-100 $\mu \mathrm{M}$ of BDE-209, with cytotoxicity only being evident at concentrations $>10 \mu \mathrm{M}$. In comparison, at the highest concentration of the $\mathrm{Br}$ mixture tested, BDE-209 is present at only $0.11 \mu \mathrm{M}$. Giordano et al. (2008) demonstrated that a technical mixture of PBDEs induces oxidative stress in rat cerebellar granule neurons. Time and concentrationdependent induction of ROS in HepG2 cells by BDE-209 has been observed with effects only appearing after exposure to concentrations $>10 \mu \mathrm{M}$ (Hu et al. 2007). They concluded that BDE-209 inhibited the proliferation of Hep G2 cells by inducing apoptosis through ROS generation. In the present study increased ROS were detected after $2 \mathrm{~h}$ and $48 \mathrm{~h}$ exposure to the highest concentration of the $\mathrm{Br}$ mixture (Figure 5). As the concentrations of PBDEs in the $\mathrm{Br}$ mixture used here are much 
lower in comparison to other studies, it may be possible that even at low concentrations PBDEs induce ROS generation but that it does not lead to apoptosis.

The addition of the $\mathrm{Br}$ mixture to the PFC mixture produced some interesting results. As the concentrations of PFCs present in the combined mixture is the same as in the PFC mixture alone, it might be expected that toxicity would stay the same or increase. Further effects were observed in HepG2 cells after $2 \mathrm{~h}$ exposure to the highest concentration of the PFC $+\mathrm{Br}$ mixture (10000 times serum levels) for NA and NI (decreased and increased respectively); there were no significant effects at this concentration for either the PFC or $\mathrm{Br}$ mixture alone (Figure 2). These changes in nuclear parameters are indicative of apoptosis. Furthermore, significant synergistic effects $(p \leq 0.05)$ were evident for the PFC $+\mathrm{Br}$ for MM (at 10000 times serum levels) and ROS (5000 times serum levels). In addition, $48 \mathrm{~h}$ exposure to this combined mixture resulted in synergistic effects observed for ROS production at two concentrations (1000 and 5000 times serum levels), while additive effects occurred at 500 and 10000 times serum levels. As PBDEs and PFCs are known to induce oxidative stress the synergy observed for MM and ROS is plausible. health. It is not a simple scenario of the more POPs present, the more risk to health; the issue is more complex. In addition to what has previously been discussed for ROS production, this is highlighted by comparing all mixtures at 1000 and 500 times the levels found in human serum. MM was increased after $48 \mathrm{~h}$ exposure to the $\mathrm{Cl}$ mixture. However no such increase was evident after 48 $\mathrm{h}$ exposure to the PFC $+\mathrm{Cl}$ mixture. Similarly $2 \mathrm{~h}$ exposure to the $\mathrm{Br}$ mixture alone, at 1000 times serum levels, caused $\mathrm{MM}$ to increase. However $2 \mathrm{~h}$ exposure to the $\mathrm{Br}+\mathrm{Cl}$ mixture had no significant effects. Furthermore the total mixture, which contains all of the individual POPs, had no cytotoxic effects at any concentration. This highlights the complexity of investigating mixtures. It is also understandable that determining the toxicity of complex mixtures is considered one of the most important challenges for modern toxicology (Fent 2003; Kortenkamp 2007; Vaiseman 2011). All of 
present study used HCA as a comparable but novel approach for investigating the toxicity of POP mixtures via multiple and pre-lethal toxicity markers.

Due to the requirement for a proliferating cell model in predictive cytotoxicity studies, the suitability of the HepG2 cell line in this role is supported by other studies. However as the results from HCA have now been deemed as comparable to other studies, a cell line with metabolic competence more akin to the in vivo state would likely further enhance the predictivity of this assay. An immortalised hepatic cell line (such as THLE2 or THLE3), which is capable of metabolic bioactivation, would enhance the biological significance of further POP studies by HCA.

Although the concentrations investigated in this study were tested above the reported concentrations of POPs in Scandinavian human serum, exposure to POPs is individualistic in nature and certain groups of people may thus have higher levels of specific compounds in their blood. Elderly people often have higher concentrations of POPs present in their serum (Salihovic et al. 2012) as POPs tend to bioaccumulate and their concentrations increase with age. Furthermore, people in countries who consume "traditional" foods such as whale blubber may have higher levels of POPs present in their serum (Van Oostdam et al. 2005; Weihe et al. 1996; Weihe et al. 2008). Finally, levels of certain compounds may be higher in specific groups of people due to occupational exposure. These differences emphasise that the present study is useful for investigating the mechanisms by which POP mixtures can exert their effects, and may especially for any higher risk groups highlight possible health risks.

\section{Conclusions}

The present study is focused on developing an improved understanding of POP mixture induced toxicity. The combination of different markers allows stronger inferences to be made about the action of the POP mixtures on HepG2 cells. The $\mathrm{Br}$ and $\mathrm{Cl}$ mixtures were able to induce ROS generation but it did not lead to apoptosis. The PFC mixture induced the production of ROS and likely induced cell apoptosis accompanied by the dissipation of MMP. Comparison of the PFC $+\mathrm{Br}$ 

conventional toxicity assays such as the MTT assay by simultaneously measuring multiple parameters. Consequently, HCA is more predictive because a wider spectrum of effects is assessed.

to the $\mathrm{Cl}$ mixture, which conventional assays would have missed. Further study on mixtures, relevant of research.

\section{Acknowledgements}

This study was supported by PhD Studentship funding provided by the Department of Agriculture and Rural Development (DARD) Northern Ireland and also by the Norwegian Research Council Project: $21307 / \mathrm{H} 10$.

References

Abraham, V.C., Taylor, L., and Haskins, J.R. (2004). High content screening applied to large-scale cell biology. Trends in Biotechnology; 22, 15-72.

Aims, B.N, Shinegava, M.K., Hagen, T.M. (1993). Oxidants, antioxidants and the degenerative diseases. Proceedings of the National Academy of Sciences USA; 90, 7915-7922.

Atlante, A. Calissano, P., Bobba, A., Azzariti, A., Marra, E., Passarella, S. (2000). Cytochrome $c$ is released from mitochondria in a reactive oxygen species (ROS)-dependent fashion and can operate as a ROS scavenger and as a respiratory substrate in cerebellar neurons undergoing excitotoxic death. The Journal of Biological Chemistry; $275,37159-37166$.

Bachour, G., Failing, K., Georgii, S., Elmadfa, I., Brunn, H. (1998). Species and organ dependence of PCB contamination in fish, foxes, roe deer, and humans. Archives of Environmental Contamination and Toxicology; $35,666-673$.

Beesoon, S., Webster, G.M., Shoeib, M., Harner, T., Benskin, J.P., Martin, J.W. (2011). Isomer profiles of perfluorochemicals in matched maternal, cord, and house dust samples: manufacturing sources and transplacental transfer. Environmental Health Perspectives; 119, 1659-1664. mitochondrial permeability transition pore. Effect of protons and divalent cations. The Journal of Biological Chemistry; 267, 2934-2939.

Berntsen, H.F., Berg, V., Thomsen, C., Lyche, J.L, Ropstad, E., Zimmer, K.E. (2015). The Synthesis of an Environmentally Relevant Mixture of Persistent Organic Pollutants for Use in In Vivo and In Vitro Studies. 
Bi, X., Qu, W., Sheng, G., Zhang, W., Mai, B., Chen, D., Yu, L., Fu, J. (2006). Polybrominated diphenyl ethers in South China maternal and fetal blood and breast milk. Environmental Pollution; 144(3), 1024-1030.

Bonde, J.P., Toft, G., Rylander, L., Rignell-Hydbom, A., Giwercman, A., Spano, M., Manicardi, G.C., Bizzaro, D., Ludwicki, J.K., Zvyezday, V., Bonefeld-Jørgensen, E.C., Pedersen, H.S., Jönsson, B.A., Thulstrup, A.M. (2008). Fertility and markers of male reproductive function in Inuit and European populations spanning large contrasts in blood levels of persistent organochlorines. Environmental Health Perspectives; 116, 269-277. Pharmacology; 39, 363-380.

Bytingsvik, J., Lie, E., Aars, J., Derocher, A.E., Wiig, Ø., Jenssen, B.M. (2012). PCBs and OH-PCBs in polar bear

Dewailly, E., Ayotte, P., Bruneau, S., Gingras, S., Belles-Isles, M., Roy, R. (2000). Susceptibility to infections and immune status in Inuit infants exposed to organochlorines. Environmental Health Perspectives; 108, 205-211.

de Wit, C., Fisk, A., Hobbs, K., Muir, D., Gabrielsen, G., Kallenborn, R., Krahn, M.M., Norstrom, R., Skaare, J. (2004). AMAP Assessment 2002: Persistent Organic Pollutants in the Arctic. Arctic Monitoring and Assessment Program, Oslo, Norway, xvi + 310pp.

de Wit, C.A., Herzke, D., Vorkamp, K. (2010). Brominated flame retardants in the Arctic environment-Trends and new candidates. Science of the Total Environment; 408, 2885-2918.

Ellis-Hutchings, R.G., Cherr, G.N., Hanna, L.A., Keen, C.L. (2006). Polybrominated diphenyl ether (PBDE)induced alterations in vitamin $A$ and thyroid hormone concentrations in the rat during lactation and early postnatal development. Toxicology and Applied Pharmacology; 215(2), 135-145.

Fei, C., McLaughlin, J., Lipworth, L., Olsen, J. (2009). Maternal levels of perfluorinated chemicals and subfecundity. Human Reproduction; 1(1), 1-6.

Fent K. (2003). Ecotoxicological problems associated with contaminated sites. Toxicology Letters; 140, 353365.

Florentin, A., Deblondea, T., Diguioa, N., Hautemanierea, A., Hartemanna, P. (2011). Impacts of two perfluorinated compounds (PFOS and PFOA) on human hepatoma cells: Cytotoxicity but no genotoxicity? International Journal of Hygiene and Environmental Health; 214, 493- 499.

Giordano, G., Kavanagh, T.J., Costa, L.G. (2008). Neurotoxicity of a polybrominated diphenyl ether mixture (DE71) in mouse neurons and astrocytes is modulated by intracellular glutathione levels. Toxicology and Applied Pharmacology; 232(2), 161-168.

Giuliano, K.A., Haskins, J.R., Taylor, D.L. (2003). Advances in high content screening for drug discovery. Assay and Drug Development Technologies; 1, 565-577.

Gottlieb, E., Armour, S.M., Harris, M.H., Thompson, C.B. (2003). Mitochondrial membrane potential regulates matrix configuration and cytochrome $c$ release during apoptosis. Cell Death and Differentiation; 10, 709-717.

Grandjean, P., Henriksen, J.E., Choi, A.L., Petersen, M.S., Dalgård, C., Nielsen, F., Weihe, P. (2011). Marine food pollutants as a risk factor for hypoinsulinemia and type 2 diabetes. Epidemiology; 22(3), 410-417.

Hallgren, S., Darnerud, P.O. (2002). Polybrominated diphenyl ethers (PBDEs), polychlorinated biphenyls (PCBs) and chlorinated paraffins (CPs) in rats-testing interactions and mechanisms for thyroid hormone effects. Toxicology; 177(2-3), 227-243. 
Halliwell, B., Gutteridge, J.M.C. (1999). Free radicals in biology and medicine. Oxford: Oxford University Press.

Harley, K.G., Marks, A.R., Chevrier, J., Bradman, A., Sjödin, A., Eskenazi, B. (2010). PBDE concentrations in women's serum and fecundability. Environmental Health Perspectives; 118(5), 699-704.

Haug, L.S., Thomsen, C., Brantsaeter, A.L., Kvalem, H.E., Haugen, M., Becher, G., Alexander, J., Meltzer, H.M., Knutsen, H.K. (2010). Diet and particularly seafood are major sources of perfluorinated compounds in humans. Environment International; 36, 772-778.

He, P., He, W, Wang, A., Xia, T., Xu, B., Zhang, M., Chen, X. (2008). PBDE-47-induced oxidative stress, DNA damage and apoptosis in primary cultured rat hippocampal neurons. Neurotoxicology; 29(1), 124-129.

He, W., He, P., Wang, A., Xia, T., Xu, B., Chen X. (2009). Effects of PBDE-47 on cytotoxicity and genotoxicity in human neuroblastoma cells in vitro. Mutation Research; 8; 649(1-2), 62-70.

Heilmann, C., Grandjean, P., Weihe, P., Nielsen, F., Budtz-Jørgense, E. (2006). Reduced Antibody Responses to Vaccinations in Children Exposed to Polychlorinated Biphenyls. PLoS Med 3(8): e311.

Hu, X.Z and Hu, D.C. (2009). Effects of perfluorooctanoate and perfluorooctane sulfonate exposure on hepatoma Hep G2 cells. Archives of Toxicology; 83, 851-861.

Hu, X.Z., Xu, Y., Hu, D.C., Hui, Y., Yang, F.X. (2007). Apoptosis induction on human hepatoma cells Hep G2 of decabrominated diphenyl ether (PBDE-209). Toxicology Letters; 15; 171(1-2), 19-28.

Inoue, K., Okada, F., Ito, R., Kato, S., Sasaki, S., Nakajima, S., Uno, A., Saijo, Y., Sata, F., Yoshimura, Y., Kishi, R., Nakazawa, H. (2004). Perfluorooctane Sulfonate (PFOS) and Related Perfluorinated Compounds in Human Maternal and Cord Blood Samples: Assessment of PFOS Exposure in a Susceptible Population during Pregnancy. Environmental Health Perspectives; 112, 1204-1207.

Johansson, N., Fredriksson, A., Eriksson, P. (2008). Neonatal exposure to perfluorooctane sulfonate (PFOS) and perfluorooctanoic acid (PFOA) causes neurobehavioural defects in adult mice. Neurotoxicology; 29, 160-169.

Johansson, N., Eriksson, P., Viberg, H. (2009) Neonatal exposure to PFOS and PFOA in mice results in changes in proteins which are important for neuronal growth and synaptogenesis in the developing brain. Toxicological Science; 108, 412-418.

Kerr, J.F., Wyllie, A.H., Currie, A.R. (1972). Apoptosis: a basic biological phenomenon with wide-ranging implications in tissue kinetics. British Journal of Cancer; 26(4), 239-257.

Knutsen, H.K., Kvalem, H. E., Thomsen, C., Froshaug, M., Haugen, M., Becher, G., Alexander, J., Meltzer, H. M. (2008). Dietary exposure to brominated flame retardants correlates with male blood levels in a selected group of Norwegians with a wide range of seafood consumption. Molecular Nutrition and Food Research; 52, 217227.

Kortenkamp, A. (2007). Ten years of mixing cocktails: a review of combination effects of endocrine-disrupting chemicals. Environmental Health Perspectives; 115, 98-105.

Kuriyama, S.N., Talsness, C.E., Grote, K., Chahoud, I. (2005). Developmental exposure to low dose PBDE 99: effects on male fertility and neurobehavior in rat offspring. Environmental Health Perspectives; 113(2), 149-54.

Letcher, R.J., Bustnes, J.O., Dietz, R., Jenssen, B.M., Jørgensen, E.H., Sonne, C., Verreault, J., Vijayan, M.M., and Gabrielsen, G.W. (2010). Exposure and effects assessments of persistent organohalogen contaminants in arctic wildlife and fish. Science of the Total Environment; 408, 2995-3040.

Lindstrom, A.B., Strynar, M.J., Libelo, E.L. (2011). Polyfluorinated compounds: past, present, and future. Environmental Science and Technology; 45(19), 7954-7961. 
Liu, J., Song, E., Liu, L., Ma, X., Tian, X., Dong, H., Song, Y. (2012). Polychlorinated biphenyl quinone metabolites lead to oxidative stress in HepG2 cells and the protective role of dihydrolipoic acid. Toxicology in Vitro; 26, 841-848

Llorca, M., Farré, M., Picó, Y., Teijón, M.L., Alvarez, J.G., Barceló, D. (2010). Infant exposure of perfluorinated compounds: levels in breast milk and commercial baby food. Environment International; 36(6), 584-592.

Longnecker, M.P., Gladen, B.C., Cupul-Uicab, L.A., Romano-Riquer, S.P., Weber, J.P., Chapin, R.E., HernandezAvila, M. (2007). In utero exposure to the antiandrogen 1,1-dichloro-2,2-bis(p-chlorophenyl)ethylene (DDE) in relation to anogenital distance in male newborns from Chiapas, México. American Journal of Epidemiology; 165 (9), 1015-1022.

Lyche, J.L., Nourizadeh-Lillabadi, R., Karlsson, C., Stavik, B., Berg, V., Skåre, J.U., Alestrøm, P., Ropstad, E. (2011). Natural mixtures of POPs affected body weight gain and induced transcription of genes involved in weight regulation and insulin signaling. Aquatic Toxicology; 102, 197-204.

Madia, F., Giordano, G., Fattori, V., Vitalone, A., Branchi, I., Capone, F., Costa, L.G. (2004). Differential in vitro neurotoxicity of the flame retardant PBDE-99 and of the PCB Aroclor 1254 in human astrocytoma cells. Toxicology Letters; 154(1-2), 11-21.

Minamikawa, T., Williams, D.A., Bowser, D.N., Nagley, P. (1999). Mitochondrial Permeability Transition and Swelling Can Occur Reversibly without Inducing Cell Death in Intact Human Cells. Experimental Cell Research; 246, 26-37.

Muir, D.C.G. and de Wit, C.A. (2010). Trends of legacy and new persistent organic pollutants in the circumpolar arctic: overview, conclusions, and recommendations. Science of the Total Environment; 408, 3044-3051.

Norbury, C.J. and Hickson, I.D. (2001). Cellular responses to DNA damage. Annual Review of Pharmacology and Toxicology; 41, 367-401.

O'Brien, P. (2008). High content analysis of sublethal cytotoxicity in human HepG2 hepatocytes for assessing potential and mechanism for chemical and drug induced human toxicity. High Content Screening (Science, Techniques, and Applications) (Haney, S.A). Wiley, NJ, pp. 293-315.

O’Brien, P. (2014). High-Content Analysis in Toxicology: Screening Substances for Human Toxicity Potential, Elucidating Subcellular Mechanisms and In Vivo Use as Translational Safety Biomarkers. Basic and Clinical Pharmacology and Toxicology; 115, 4-17.

O’Brien, P. and Haskins, J.R. (2007). In vitro cytotoxicity assessment. In: Taylor, D.L., Haskins, J.R., Giuliano, K.A. (Eds.), High Content Screening (Methods in Molecular Biology), Humana Press, NJ, USA, pp. 415-425.

O’Brien, P.J., Irwin, W., Diaz, D., Howard-Cofield, E., Krejsa, C.M., Slaughter, M.R., Gao, B., Kaludercic, N., Angeline, A., Bernardi, P., Brain, P., Hougham, C. (2006). High concordance of drug-induced human hepatotoxicity with in vitro cytotoxicity measured in a novel cell-based model using high content screening. Archives of Toxicology; 80, 580-604.

Ode, A., Rylander, L., Lindh, C.H., Kallen, K., Jonsson, B.A., Gustafsson, P., Olofsson, P., Ivarsson, S.A., RignellHydbom, A. (2013). Determinants of maternal and fetal exposure and temporal trends of perfluorinated compounds. Environmental Science and Pollution Research; 20, 7970-7978.

Panaretakis, T., Shabalina, I.G., Grander, D., Shoshan, M.C., De Pierre, J.W. (2001) Reactive oxygen species and mitochondria mediate the induction of apoptosis in human hepatoma HepG2 cells by the rodent peroxisome proliferator and hepatocarcinogen, perXuorooctanoic acid. Toxicology and Applied Pharmacology; 173, 56-64.

Pereg, D., Ryan, J.J., Ayotte, P., Muckle, G., Patry, B., Dewailly, E. (2003). Temporal and spatial changes of brominated diphenyl ethers (BDEs) and other POPs in human milk from Nunavik (Arctic) and southern Quebec. Organohalogen Compounds; 61, 127-130. 
Persky, V., Turyk, M., Anderson, A. (2001). The effects of PCB exposure and fish consumption on endogenous hormones. Environmental Health Perspectives; 109, 1275-1283.

Petronilli, V., Nicolli, A., Costantini, P., Colonna, R., Bernardi, P. (1994). Regulation of the permeability transition pore, a voltage-dependent mitochondrial channel inhibited by cyclosporine A. Biochimica et Biophysica Acta; 1187, 255-259.

Pinti, M., Troiano, L., Nasi, M., Ferraresi, R., Dobrucki, J., Cossarizza, A. (2003). Hepatoma HepG2 cells as a model for in vitro studies on mitochondrial toxicity of antiviral drugs: which correlation with the patient? Journal of Biological Regulators \& Homeostatic Agents; 17(2), 166-171.

Polder, A., Skaare, J.U., Skjerve, E., Loken, K.B., Eggesbo, M. (2009). Levels of chlorinated pesticides and polychlorinated biphenyls in Norwegian breast milk (2002-2006), and factors that may predict the level of contamination. Science of the Total Environment; 407, 4584-4590.

Polder, A., Thomsen, C., Lindstrom, G., Loken, K.B., Skaare, J.U. (2008). Levels and temporal trends of chlorinated pesticides, polychlorinated biphenyls and brominated flame retardants in individual human breast milk samples from Northern and Southern Norway. Chemosphere, 73, 14-23.

Reistad, T., Fonnum, F., Mariussen, E. (2006). Neurotoxicity of the pentabrominated diphenyl ether mixture, $\mathrm{DE}-71$, and hexabromocyclododecane (HBCD) in rat cerebellar granule cells in vitro. Archives of Toxicology; 80(11), 785-796.

Ricci, J.E., Gottlieb, R.A., Green, D.R. (2003) Caspase-mediated loss of mitochondrial function and generation of reactive oxygen species during apoptosis. Journal of Cell Biology; 160, 65-75.

Ritter, L., Solomon, K.R., Forget, J., Stemeroff, M., O'Leary, C. (1995). Persistent organic pollutants. United Nations Environment Programme. Retrieved 15.05.15.

Salihovic, S., Lampa, E., Lindström, G., Lind L., Lind, P.M., van Bavel, B. (2012). Circulating levels of Persistent Organic Pollutants (POPs) among elderly men and women from Sweden: Results from the Prospective Investigation of the Vasculature in Uppsala Seniors (PIVUS). Environment International; 40, 170-178.

Schreiber, T., Gassmann, K., Götz, C., Hubenthal, U., Moors, M., Krause, G., Merk, H.F., Nguyen, N.H., Scanlan, T.S., Abe, J., Rose, C.R., Fritsche, E. (2010). Polybrominated Diphenyl Ethers Induce Developmental Neurotoxicity in a Human in Vitro Model: Evidence for Endocrine Disruption. Environmental Health Perspectives; 118(4), 572-578.

Shabalina, I.G., Panaretakis, T., Bergstrand, A., DePierre, J.W. (1999). Effects of the rodent peroxisome proliferator and hepatocarcinogen, Perfluorooctanoic acid, on apoptosis in human hepatoma HepG2 cells. Carcinogenesis; 20, 2237-2246.

Shao, J., White, C.C., Dabrowski, M.J., Kavanagh, T.J., Eckert, M.L., Gallagher, E.P. (2008). The role of mitochondrial and oxidative injury in BDE 47 toxicity to human fetal liver hematopoietic stem cells. Toxicological Sciences; 101(1), 81-90.

Simizu, S., Takada, M., Umezawa, K., Imoto, M. (1998) Requirement of caspase-3(-like) protease-mediated hydrogen peroxide production for apoptosis induced by various anticancer drugs. Journal of Biological Chemistry; 273, 26900-26907.

Sjödin, A., Hagmar, L., Klasson-Wehler, E., Kronholm-Diab, K., Jakobsson, E., Bergman, A. (1999). Flame retardant exposure: polybrominated diphenyl ethers in blood from Swedish workers. Environmental Health Perspectives; 107(8), 643-648.

Sjödin, A., Wong, L.Y., Jones, R.S., Park, A., Zhang, Y., Hodge, C., Dipietro, E., McClure, C., Turner, W., Needham, L.L., Patterson, D.G. Jr. (2008). Serum concentrations of polybrominated diphenyl ethers (PBDEs) and polybrominated biphenyl (PBB) in the United States population: 2003-2004. Environmental Science and Technology; 15, 42(4), 1377-1384. 
United Nations Environment Program (UNEP), Final Act of the Conference of Plenipotentiaries on The Stockholm Convention on Persistent Organic Pollutants, Stockholm, Sweden, 22 to 23 May 2001 (UNEP, Geneva, Switzerland, 2001).

662 Vaiseman, A. (2011). Early-life origin of adult disease: evidence from natural experiments. Experimental 663 Gerontology; 46, 189-192.

664 Van Oostdam, J.C., Dewailly, E., Gilman, A., Hansen, J.C., Odland, J.O., Chashchin, V., Bernenr, J., Butler-Walker, 665 J., Lagerkvist, B. J., Olafsdottir, K., Soininen, L., Bjerregard, P., Klopov, V., Weber, J.P. (2004). Circumpolar maternal blood contaminant survey, 1994-1997 organochlorine compounds. Science of the Total Environment; 330, 55-70.

668

669

670

671

Van Oostdam, J., Donaldson, S.G., Feeley, M., Arnold, D., Ayotte, P., Bondy, G., Chan, L., Dewaily, E., Furgal, C.M., Kuhnlein, H., Loring, E., Muckle, G., Myles, E., Receveur, O., Tracy, B., Gill, U., Kalhok, S. (2005). Human health implications of environmental contaminants in Arctic Canada: A review. Science of the Total 672 Environment; 352, 165-246

Van Oostdam, J., Donaldson, S.G, Feeley, M., Tremblay, N. (2003). Toxic Substances in the Arctic and Affairs and Northern Development, Canada.

Viberg, H., Fredriksson, A., Eriksson, P. (2003). Neonatal exposure to polybrominated diphenyl ether (PBDE 153) disrupts spontaneous behaviour, impairs learning and memory, and decreases hippocampal cholinergic receptors in adult mice. Toxicology and Applied Pharmacology; 192(2), 95-106.

Waliszewski, S.M., Melo-Santiesteban, G., Villalobos-Pietrini, R., Gómez-Arroyo, S., Amador-Muñoz, O., 680 Herrero-Mercado, M., Carvajal, O. (2009). Breast milk excretion Kinetic of b-HCH, pp'DDE and pp'DDT. Bulletin 681 of Environmental Contamination and Toxicology; 83(6), 869-873.

682 Walsh, E.G., Maher, S., Devocelle, M., O’Brien, P.J., Baird, A.W., Brayden, D.J. (2011). High content analysis to 683 determine cytotoxicity of the antimicrobial peptide melittin and selected structural analoques. Peptides; 32 , 684 1764-1773.

Weber, F., Freudinger, R., Schwerdt, G., Gekle, M. (2005). A rapid screening method to test apoptotic synergisms of ochratoxin A with other nephrotoxic substances. Toxicology In Vitro; 19, 135-143.

687 Weihe, P., Kato, K., Calafat, A.M., Nielsen, F., Wanigatunga, A.A., Needham, L.L. (2008). Serum concentrations 688 of polyfluoroalkyl compounds in Faroese whale meat consumers. Environmental Science and Technology; 689 42(16), 6291-6295.

690 Weihe, P., Grandjean, P., Debes, F., White, R. (1996). Health implications for Faroe Islanders of heavy metals 691 and PCBs from pilot whales. Science of the Total Environment; 186, 141-148.

White, S.S., Fenton, S.E., Hines, E.P. (2011). Endocrine disrupting properties of perfluorooctanoic acid. Journal of Steroid Biochemistry and Molecular Biology; 127(1-2), 16-26.

694 Zeiss, C.J. (2003). The apoptosis-necrosis continuum: insights from genetically altered mice. Veterinary 695 Pathology; 40(5), 481-495. 
Table 1. The composition and concentrations of original stocks supplied by the Norwegian University of Life Sciences, Oslo. The estimated concentration of POPs in the Total, $\mathrm{Cl}, \mathrm{PFC}+\mathrm{Cl}$ and $\mathrm{Br}+\mathrm{Cl}$ stock solutions are $1,000,000$ times the estimated concentrations in human serum, in comparison with the $\mathrm{PFC}, \mathrm{Br}$ and $\mathrm{PFC}+\mathrm{Br}$ stock solutions where the estimated concentration of POPs are 10,000,000 times the estimated concentrations in human serum.

704

\begin{tabular}{|c|c|c|c|c|c|c|c|}
\hline \multirow{2}{*}{$\begin{array}{c}\text { Compound } \\
\text { Perfluorinated compounds (PFCs) }\end{array}$} & \multicolumn{7}{|c|}{ Mixture Stock Concentration (mg/ml) } \\
\hline & Total & PFC & $\mathrm{Br}$ & $\mathrm{Cl}$ & $\mathrm{PFC}+\mathrm{Br}$ & $\mathrm{PFC}+\mathrm{Cl}$ & $\mathrm{Br}+\mathrm{Cl}$ \\
\hline PFOA & 4.523 & 45.225 & & & 45.225 & 4.523 & \\
\hline PFOS & 29.425 & 294.250 & & & 294.250 & 29.425 & \\
\hline PFDA & 0.495 & 4.950 & & & 4.950 & 0.495 & \\
\hline PFNA & 0.800 & 8.000 & & & 8.000 & 0.800 & \\
\hline PFHxS & 3.450 & 34.500 & & & 34.500 & 3.450 & \\
\hline PFUnDA & 0.560 & 5.600 & & & 5.600 & 0.560 & \\
\hline \multicolumn{8}{|c|}{ Polybrominated diphenyl ethers (PBDEs) } \\
\hline BDE-209 & 0.011 & & 0.108 & & 0.108 & & 0.011 \\
\hline BDE-47 & 0.009 & & 0.086 & & 0.086 & & 0.009 \\
\hline BDE-99 & 0.004 & & 0.035 & & 0.035 & & 0.004 \\
\hline BDE-100 & 0.002 & & 0.022 & & 0.022 & & 0.002 \\
\hline BDE-153 & 0.001 & & 0.010 & & 0.010 & & 0.001 \\
\hline BDE-154 & 0.002 & & 0.018 & & 0.018 & & 0.002 \\
\hline $\mathrm{HBCD}$ & 0.025 & & 0.246 & & 0.246 & & 0.025 \\
\hline \multicolumn{8}{|l|}{ Polychlorinated biphenyls (PCBs) } \\
\hline РCB 138 & 0.222 & & & 0.222 & & 0.222 & 0.222 \\
\hline PCB 153 & 0.362 & & & 0.362 & & 0.362 & 0.362 \\
\hline PCB 101 & 0.008 & & & 0.008 & & 0.008 & 0.008 \\
\hline PCB 180 & 0.194 & & & 0.194 & & 0.194 & 0.194 \\
\hline PCB 52 & 0.010 & & & 0.010 & & 0.010 & 0.010 \\
\hline PCB 28 & 0.013 & & & 0.013 & & 0.013 & 0.013 \\
\hline РСB 118 & 0.064 & & & 0.064 & & 0.064 & 0.064 \\
\hline \multicolumn{8}{|l|}{ Other organochlorines } \\
\hline$p, p^{\prime}-\mathrm{DDE}$ & 0.502 & & & 0.502 & & 0.502 & 0.502 \\
\hline $\mathrm{HCB}$ & 0.117 & & & 0.117 & & 0.117 & 0.117 \\
\hline$\alpha$ - chlordane & 0.011 & & & 0.011 & & 0.011 & 0.011 \\
\hline oxy - chlordane & 0.022 & & & 0.022 & & 0.022 & 0.022 \\
\hline trans-nonachlor & 0.041 & & & 0.041 & & 0.041 & 0.041 \\
\hline$\alpha-\mathrm{HCH}$ & 0.006 & & & 0.006 & & 0.006 & 0.006 \\
\hline$\beta-\mathrm{HCH}$ & 0.053 & & & 0.053 & & 0.053 & 0.053 \\
\hline Y-HCH (Lindane) & 0.006 & & & 0.006 & & 0.006 & 0.006 \\
\hline Dieldrin & 0.024 & & & 0.024 & & 0.024 & 0.024 \\
\hline
\end{tabular}

Table 2. Summary results for all HCA parameters and the MTT assay for HepG2 cells after $2 \mathrm{~h}$ exposure to POP mixtures. Note: Total, $\mathrm{Cl}$ and PFC $+\mathrm{Cl}$ mixture results are not shown as no 
highlighted while cells with arrows indicate significant changes in that parameteshows an increase in the parameter while $\downarrow$ shows a decrease.

\begin{tabular}{|c|c|c|c|c|c|c|c|c|c|c|c|c|c|c|c|c|}
\hline \multirow{2}{*}{$\begin{array}{l}\text { Cell Health } \\
\text { Parameter }\end{array}$} & \multicolumn{4}{|c|}{ PFC Mix } & \multicolumn{4}{|c|}{ BFR Mix } & \multicolumn{4}{|c|}{ Cl Mix } & \multicolumn{4}{|c|}{ PFC + BFR Mix } \\
\hline & $\begin{array}{c}50 \\
0\end{array}$ & $\begin{array}{c}100 \\
0\end{array}$ & 5000 & $\begin{array}{c}1000 \\
0\end{array}$ & $\begin{array}{c}50 \\
0\end{array}$ & $\begin{array}{c}100 \\
0\end{array}$ & $\begin{array}{c}500 \\
0\end{array}$ & $\begin{array}{c}1000 \\
0\end{array}$ & $\begin{array}{l}5 \\
0\end{array}$ & $\begin{array}{c}10 \\
0\end{array}$ & $\begin{array}{c}50 \\
0\end{array}$ & $\begin{array}{c}100 \\
0\end{array}$ & $\begin{array}{c}50 \\
0\end{array}$ & $\begin{array}{c}100 \\
0\end{array}$ & $\begin{array}{c}500 \\
0\end{array}$ & $\begin{array}{c}1000 \\
0\end{array}$ \\
\hline $\mathrm{CN}$ & & & & $\downarrow$ & & & & & & & & & & & & \\
\hline $\mathrm{NI}$ & & & & & & & & & & & & & & & & $\uparrow$ \\
\hline NA & & & & & & & & & & & & & & & & $\downarrow$ \\
\hline MM & & & & & & $\uparrow$ & & & & & & & & & & \\
\hline MMP & & & $\downarrow$ & $\downarrow$ & & & & & & & & & & & & $\downarrow$ \\
\hline ROS & & & & $\uparrow$ & & & & $\uparrow$ & & & $\uparrow$ & $\uparrow$ & & & & $\uparrow$ \\
\hline MTT & & & $\downarrow$ & $\downarrow$ & & & & & & & & & & & & $\downarrow$ \\
\hline
\end{tabular}

Table 3. Summary results for all HCA parameters and the MTT assay for HepG2 cells after $48 \mathrm{~h}$ exposure to POP mixtures. Note: Total, $\mathrm{Cl}$ and PFC $+\mathrm{Cl}$ mixture results are not shown as no significant effects were observed at any concentration. Green indicates no significant effects were highlighted while red indicates significant changes in that parametef. shows an increase in the parameter while $\downarrow$ shows a decrease.

\begin{tabular}{|c|c|c|c|c|c|c|c|c|c|c|c|c|c|c|c|c|}
\hline & \multicolumn{4}{|c|}{ PFC Mix } & \multicolumn{4}{|c|}{ BFR Mix } & \multicolumn{4}{|c|}{ Cl Mix } & \multicolumn{4}{|c|}{ PFC + BFR Mix } \\
\hline $\begin{array}{c}\text { Health } \\
\text { Parameter }\end{array}$ & 500 & $\begin{array}{c}100 \\
0\end{array}$ & $\begin{array}{c}500 \\
0\end{array}$ & $\begin{array}{c}1000 \\
0\end{array}$ & $\begin{array}{c}50 \\
0\end{array}$ & $\begin{array}{c}100 \\
0\end{array}$ & $\begin{array}{c}500 \\
0\end{array}$ & $\begin{array}{c}1000 \\
0 \\
\end{array}$ & $\begin{array}{l}5 \\
0 \\
\end{array}$ & $\begin{array}{c}10 \\
0 \\
\end{array}$ & $\begin{array}{c}50 \\
0 \\
\end{array}$ & $\begin{array}{c}100 \\
0\end{array}$ & $\begin{array}{c}50 \\
0 \\
\end{array}$ & $\begin{array}{c}100 \\
0\end{array}$ & $\begin{array}{c}500 \\
0 \\
\end{array}$ & $\begin{array}{c}1000 \\
0\end{array}$ \\
\hline $\mathrm{CN}$ & & & $\downarrow$ & $\downarrow$ & & & & & & & & & & & $\downarrow$ & $\downarrow$ \\
\hline $\mathrm{NI}$ & & & $\uparrow$ & $\uparrow$ & & & & & & & & & & & $\uparrow$ & $\uparrow$ \\
\hline NA & & & $\uparrow$ & & & & & & & & & & & & $\uparrow$ & $\uparrow$ \\
\hline MM & & & $\uparrow$ & $\uparrow$ & & & & & & $\uparrow$ & $\uparrow$ & $\uparrow$ & & & & $\uparrow$ \\
\hline MMP & & & $\downarrow$ & $\downarrow$ & & & & & & & & & & & $\downarrow$ & $\downarrow$ \\
\hline ROS & & & & $\uparrow$ & & & & $\uparrow$ & & & & $\uparrow$ & & & & $\uparrow$ \\
\hline MTT & & & $\downarrow$ & $\downarrow$ & & & & & & & & & & & $\downarrow$ & $\downarrow$ \\
\hline
\end{tabular}




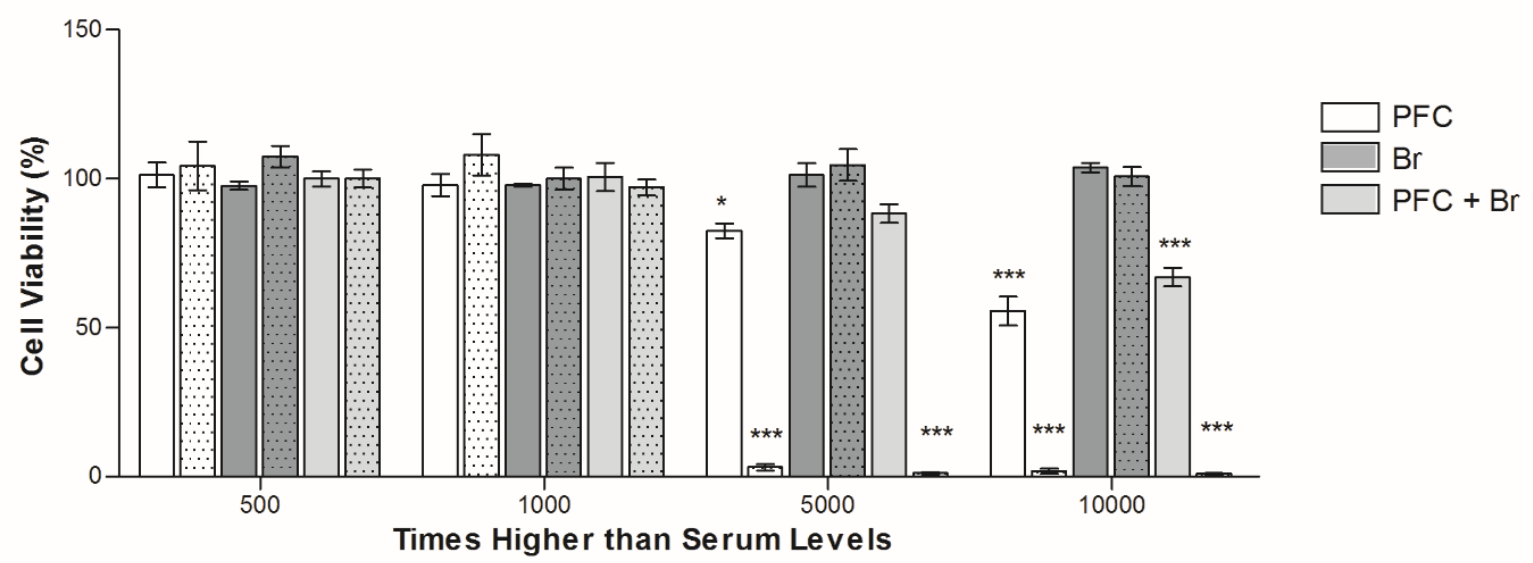

Figure 1. Cell viability of HepG2 cells after exposure to three POP mixtures, $\mathrm{PFC}, \mathrm{Br}$ and $\mathrm{PFC}+\mathrm{Br}$. Cells were exposed to concentrations of POPs (500, 1000, 5000 and 10000 times serum levels) for $2 \mathrm{~h}$ and $48 \mathrm{~h}$ and cytotoxicity measured by conventional MTT. Data is expressed as a percentage of untreated control for each parameter; mean $\pm \mathrm{SEM}, \mathrm{n}=3 . p \leq 0.05(*), p \leq 0.01\left({ }^{* *}\right)$ and $p \leq 0.001\left({ }^{* * *}\right)$ represent significant cytotoxic effects. 

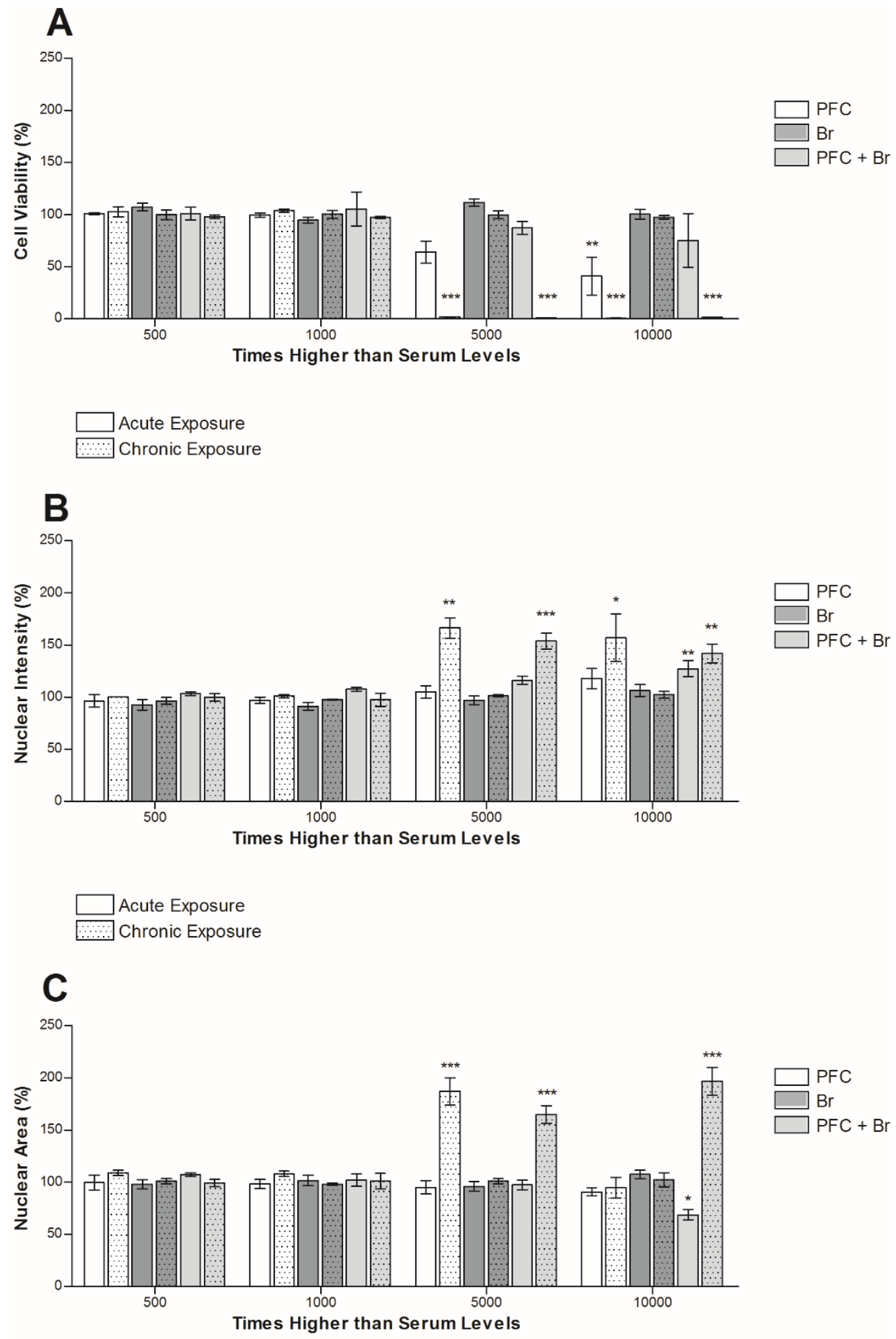

Figure 2. Nuclear changes in HepG2 cells after exposure to POP mixtures, $\mathrm{PFC}, \mathrm{Br}$ and $\mathrm{PFC}+\mathrm{Br}$. Cells were exposed to concentrations of POPs (500, 1000, 5000 and 10000 times serum levels) for $2 \mathrm{~h}$ and $48 \mathrm{~h}$ and cytotoxicity measured by multi-parameter HCA endpoints CN (A), NI (B) and NA (C). Data is expressed as a percentage of untreated control for each parameter; mean $\pm \mathrm{SEM}, \mathrm{n}=3 . p \leq 0.05(*), p \leq 0.01\left({ }^{* *}\right)$ and $p \leq 0.001$ $(* * *)$ represent significant cytotoxic effects. 


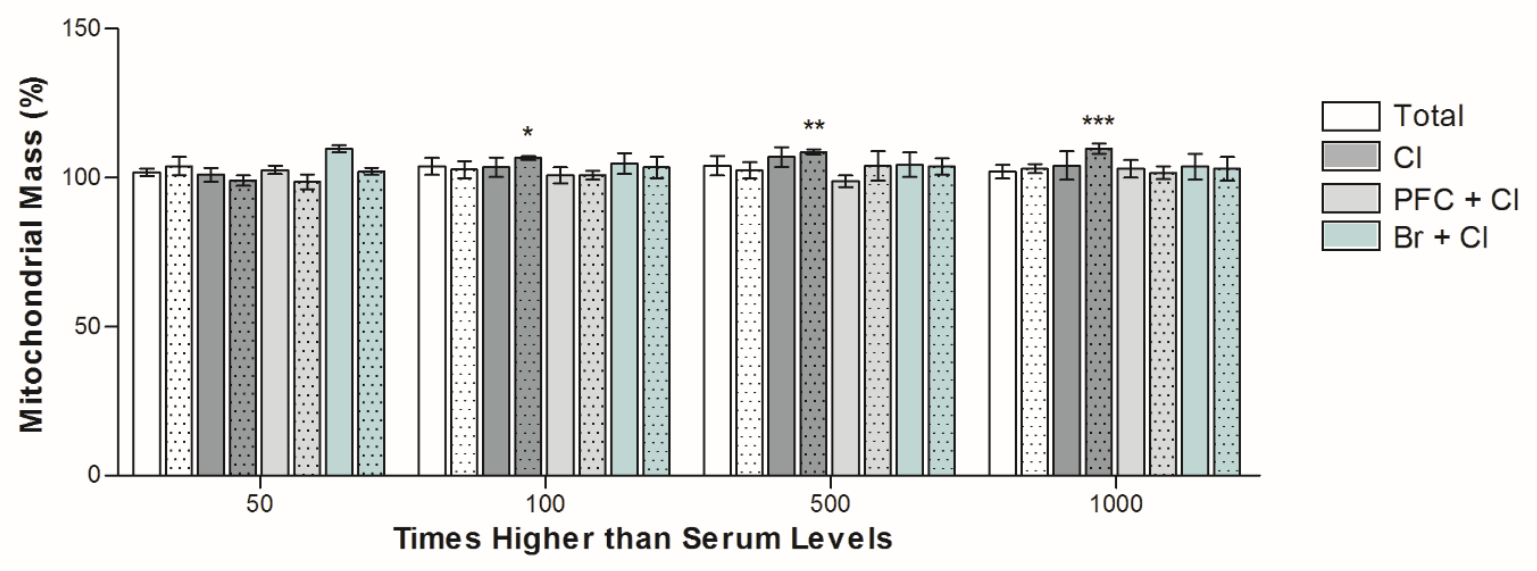

Figure 3. Mitochondrial mass changes after exposure to four POP mixtures, Total, $\mathrm{Cl}, \mathrm{PFC}+\mathrm{Cl}$ and $\mathrm{Br}+\mathrm{Cl}$, in HepG2 cells. Cells were exposed to concentrations of POPs (50, 100, 500 and 1000 times serum levels) for $2 \mathrm{~h}$ and $48 \mathrm{~h}$ and cytotoxicity measured by multi-parameter HCA endpoint MM. Data is expressed as a percentage of untreated control for each parameter; mean \pm SEM, $n=3 . \$ p 0.05(*), p \leq 0.01\left(^{* *}\right)$ and $p \leq 0.001\left({ }^{* * *}\right)$ represent significant cytotoxic effects. 

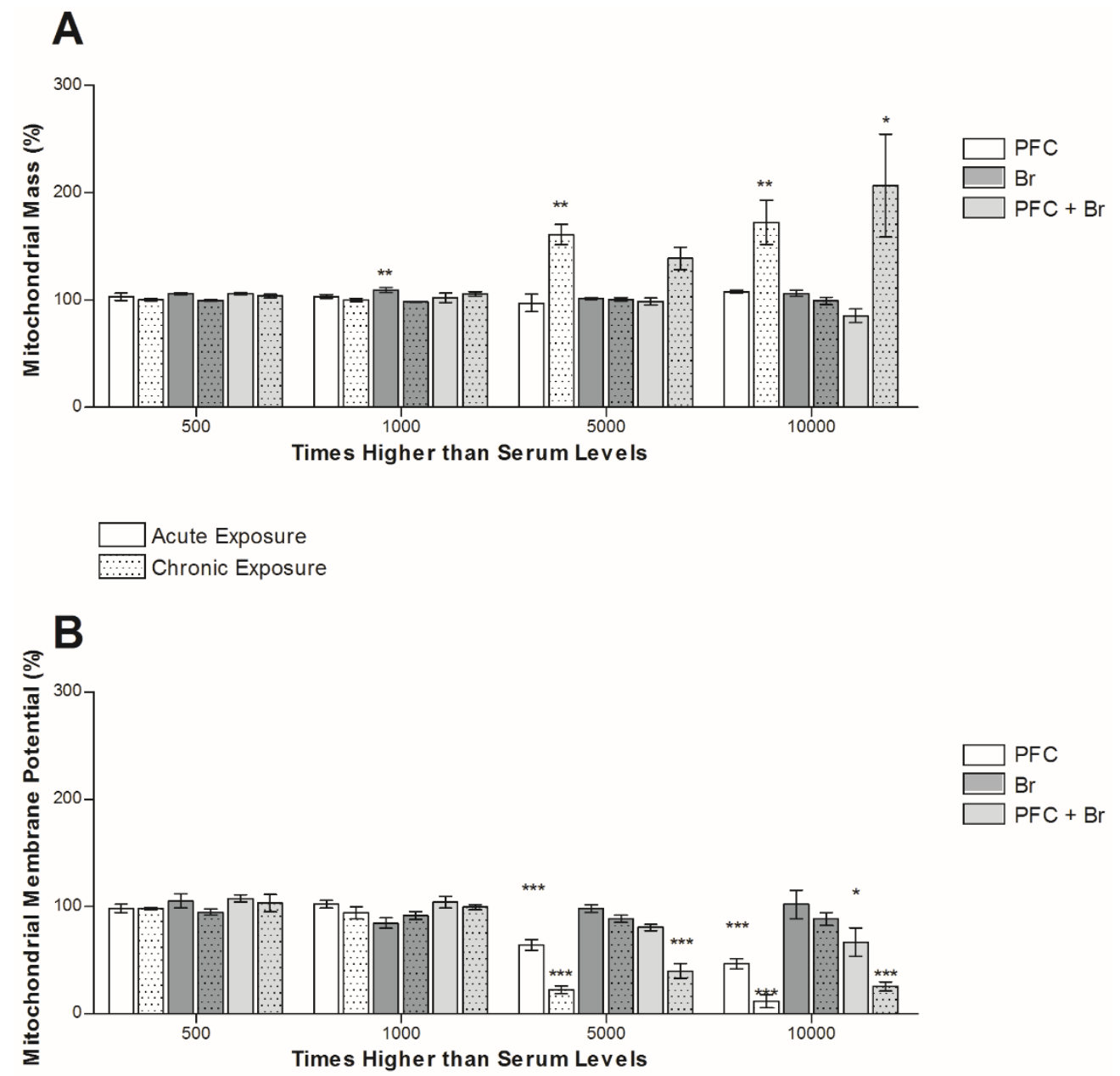

Figure 4. Mitochondrial changes after exposure to three POP mixtures, PFC, $\mathrm{Br}$ and $\mathrm{PFC}+\mathrm{Br}$, in HepG2 cells. Cells were exposed to concentrations of POPs (500, 1000, 5000 and 10000 times serum levels) for $2 \mathrm{~h}$ and $48 \mathrm{~h}$ and cytotoxicity measured by multi-parameter HCA endpoints MM (A) and MMP (B). Data is expressed as a percentage of untreated control for each parameter; mean $\pm \mathrm{SEM}, \mathrm{n}=3 . p \leq 0.05\left({ }^{*}\right), p \leq 0.01\left({ }^{* *}\right)$ and $p \leq 0.001$ $(* * *)$ represent significant cytotoxic effects. 


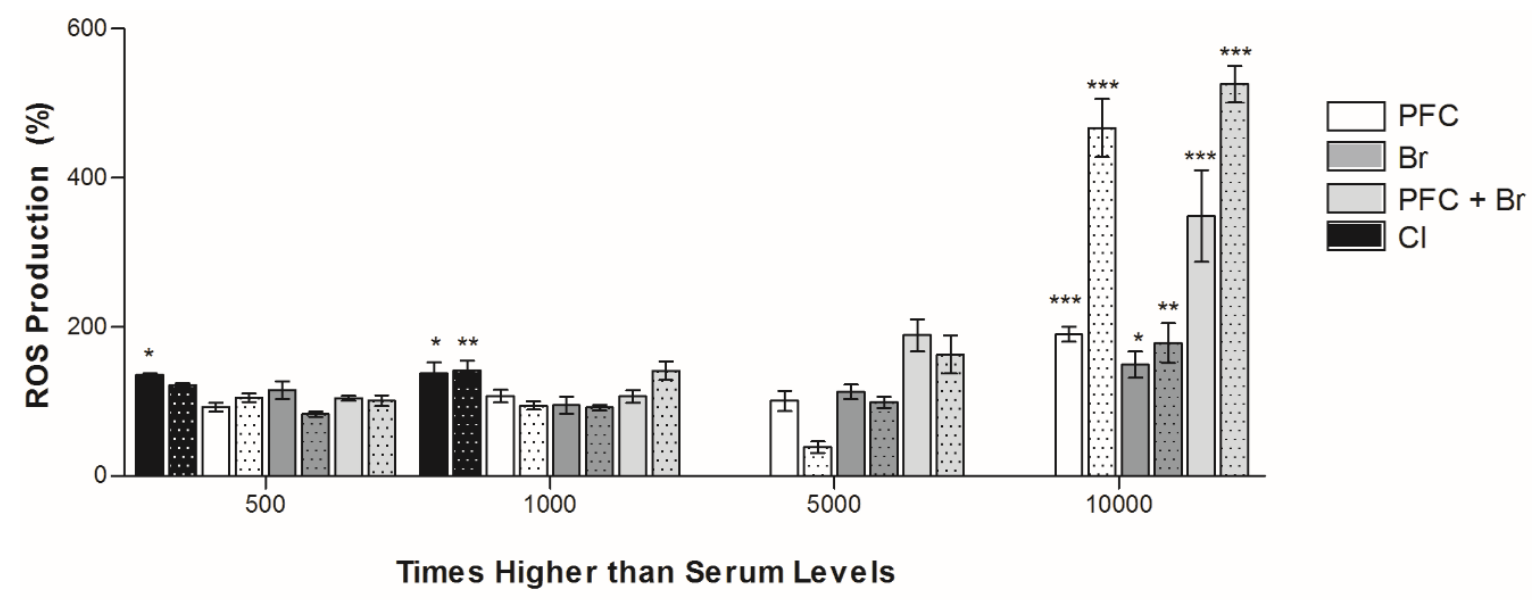

Figure 5. ROS production in HepG2 cells after exposure to four POP mixtures, $\mathrm{PFC}, \mathrm{Br}, \mathrm{PFC}+\mathrm{Br}$ and $\mathrm{Cl}$. Cells were exposed to concentrations of POPs $(500,1000,5000$ and 10000 times serum levels (NOTE $-\mathrm{Cl}$ mixture was not tested at 5000 or 10000 times serum levels) for $2 \mathrm{~h}$ and $48 \mathrm{~h}$ and cytotoxicity measured by multiparameter HCA endpoint ROS. Data is expressed as a percentage of untreated control for each parameter; mean $\pm \mathrm{SEM}, \mathrm{n}=3 . p \leq 0.05(*), p \leq 0.01\left({ }^{* *}\right)$ and $p \leq 0.001\left({ }^{* * *}\right)$ represent significant cytotoxic effects. 


\section{A}

817

818

819

820

821

822

\section{B}

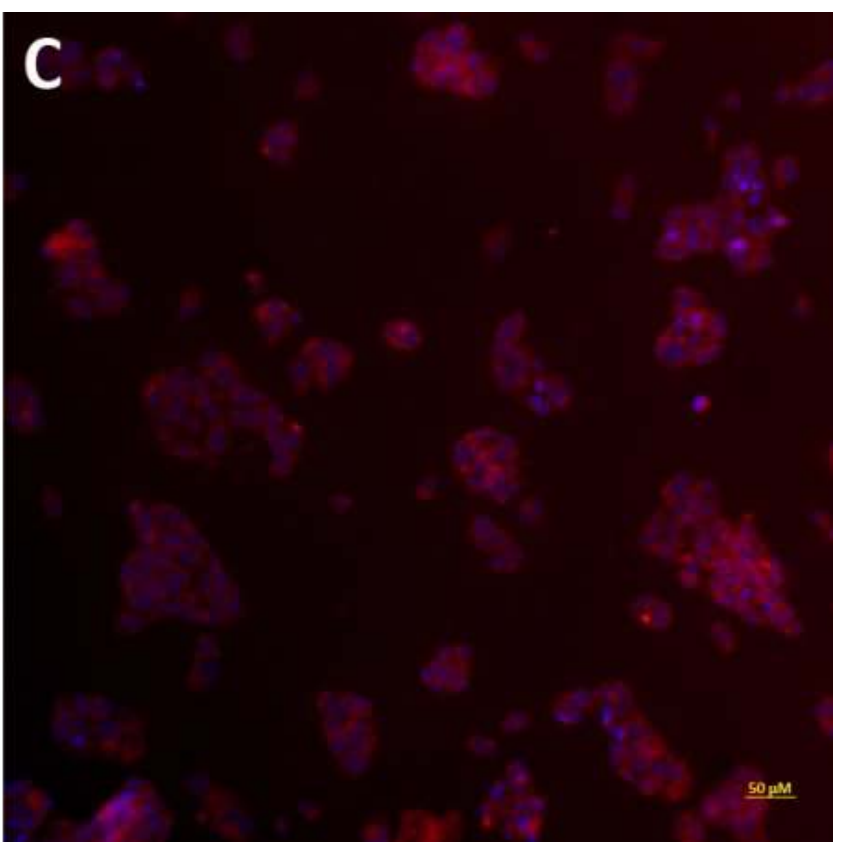

Figure 6. HCA images for (A) negative control (DMSO), (B) positive control (100 $\mu \mathrm{M}$ menadione), (C) example of mix - PFC + Br (10000 times serum level) - $2 \mathrm{~h}$ exposure. Each image was acquired at $10 \times$ objective magnification using Hoechst dye (blue; nuclear staining) and CellROX dye (red; ROS). Arrow indicates an area of increased red fluorescence due to increased ROS production. 